\title{
Concentrations of Some Trace Elements in Surface and Groundwater Resources in Agepanu and Environs, Edo State, Nigeria
}

Chinyem F. I.*

Department of Geology, Delta State University, Abraka, Nigeria, Africa; fichinyem@yahoo.com

\begin{abstract}
Concentrations of some trace elements such as $\mathrm{Zn}, \mathrm{Pb}, \mathrm{Cr}, \mathrm{Cd}, \mathrm{Ni}$ and $\mathrm{Cu}$ in surface and ground water in Agepanu and environs were evaluated after acid digestion by atomic absorption spectrophotmetry. The concentrations of the elements ranged from $0.084-0104 \mathrm{mgl}^{-1}$ for $\mathrm{Zn} ; 0.007-0.087 \mathrm{mgl}^{-1}$ for Cr, less than $0.002 \mathrm{mgl}^{-1}$ for $\mathrm{Pb}, 0.075-0.099 \mathrm{mgl}^{-1}$ for Cu ; less than $0.05 \mathrm{mgl}^{-1}$ for Cd and less than $0.002 \mathrm{mgl}^{-1}$ for Ni. The concentrations of the examined elements were below the WHO, FMEV safe limits in surface and groundwater except for chromium which was slightly higher than the safe limit in Afiangbe.
\end{abstract}

Keywords: Trace Elements, Concentrations, Safe Limit, Agepanu, Groundwater.

\section{Introduction}

Water is one of the most precious substances in the earth. It is very essential for the existence and survival of life. Surface and underground water contains major ions, trace metal and other toxic pollutants $[1,8]$. The concentration of these substances in either surface or ground water is a function of the geological environment, composition of water, effects of storm, water filtration, water movement, its velocity and use, rainfall and recharge mechanism. The increasing concentrations of trace metals in surface and groundwater has generated a lot of concern in recent time $[9,6]$. The increasing concentrations of trace elements in surface and groundwater research has generated a lot of concern in recent times and this has been attributed to human interference, proliferation of industries and recent agricultural practice in urban areas [5]. According to Meranger, et al, [7], there is an increasing interest in the groundwater quality used for drinking throughout the world.

Many elements present in drinking water are reported to be essential for human health. Nevertheless, their ingestion in excessive amounts may cause severe health problems [2]. It is therefore usually necessary to study the quality of both surface and ground water resource in the study area and suggest remedial measures to be adopted to protect the water resources from contamination. To this end the study was designed to access the surface and ground water quality with respect to trace elements at some selected sites of Agepanu and environs.

\section{Materials and Method}

\subsection{Location and Geology of the Study Area}

The study area is located between latitude $006^{\circ} 45^{\prime} \mathrm{N}$ and $006^{0} 38^{\prime} \mathrm{N}$ of the equator and longitude $005^{\circ} 30^{\prime} \mathrm{E}$ and $005^{\circ} 45^{\prime} \mathrm{E}$ of the Greenwich meridian (Figure 1). This is located in Ovia North - East local government area Edo state in the southern geographical zone. The geology constitutes part of the Niger Delta sedimentary suite. The area falls within the tropical region which is characterized by two distinct climatic seasons namely; the rainy season (April-October)

*Corresponding author:

Chinyem F. I. (fichinyem@yahoo.com) 


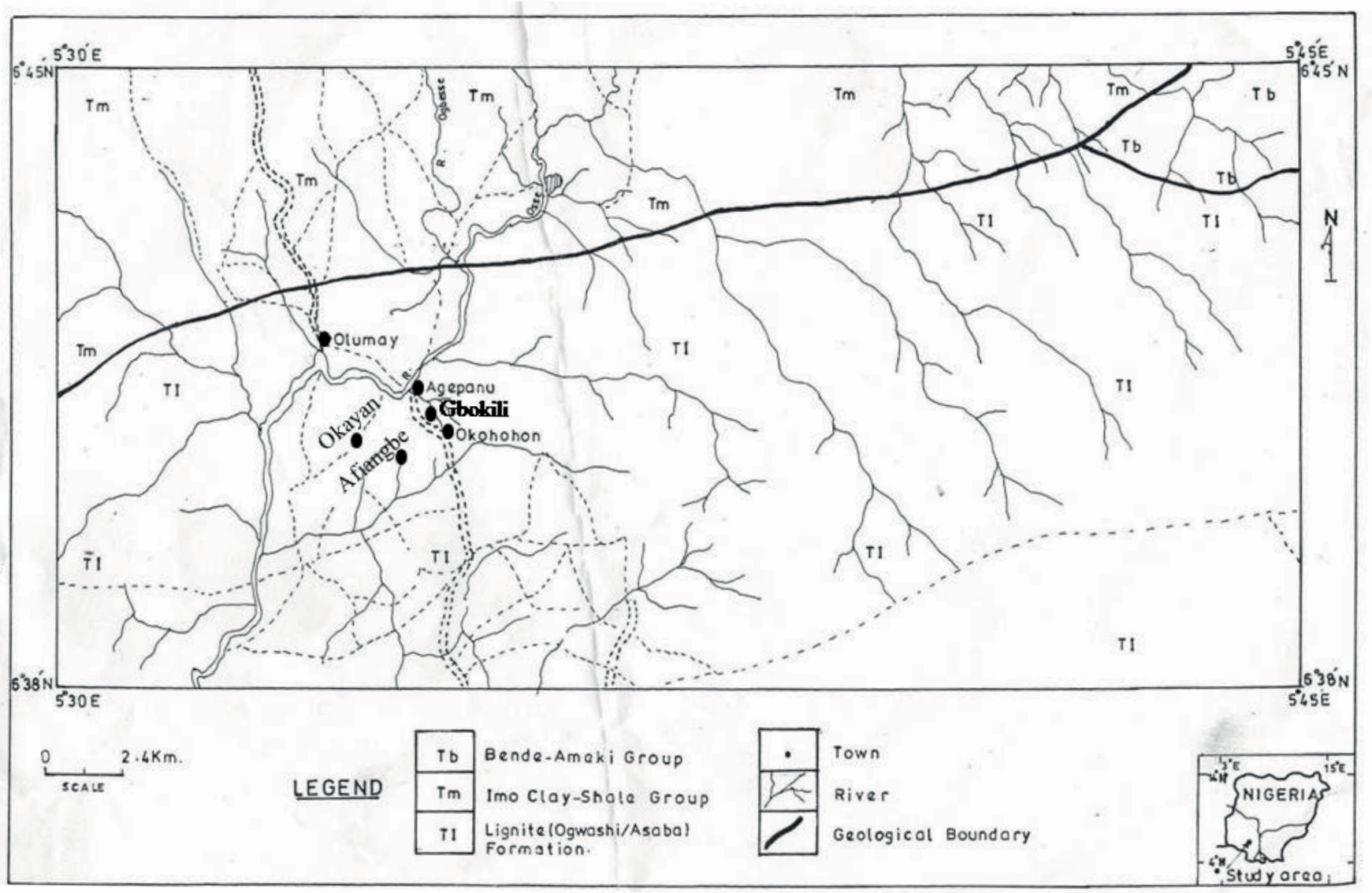

Figure 1. Base map showing the Study Area.

and dry season (November - March). Mean annual rainfall is about $250 \mathrm{~mm}$ while relative Humidity $70 \%$, average mean annual temperature is less than $28^{\circ} \mathrm{C}$.

The study area is well drained by Ogbese Ovia (which flows from Agepanu to Okanya), Afiangbe and Gbokili Rivers.

\subsection{Sampling}

The study was conducted between the month of July and October 2010. The surface water samples were collected from Afiangbe Rivers, Ogbese/Ovia River at Afiangbe and Okayan villages respectively, while the only ground water sample was collected at Gbokili village water bore hole. So, a total of three surface and one groundwater samples were collected from study area. In collecting surface water samples it was ensured that the surface water was collected from the flowing section of the river. All water samples were taken in plastic bottles and then brought to the laboratory. To stop growth of microbes few drops of toluene were added. The samples were filtered through Whatman 42 filter paper and analyzed for trace metal with the help of atomic absorption spectrophotometer. The concentration of the following trace elements such as zinc $(\mathrm{Zn})$, lead $(\mathrm{Pb})$, chromium $(\mathrm{Cr})$, cadmium $(\mathrm{Cd})$, nickel $(\mathrm{Ni})$ and copper $(\mathrm{Cu})$ were analyzed. In practice, Atomic Absorption Spectrophotometry (AAS) methodology entails the aspiration of a sample into a flame, where it becomes atomized. A light beam is directed through the flame into a monochromator and onto a detector. The detector then measures the intensity of light absorbed by the atomized elements in the flame. Thus, the amount of light intensity absorbed in the flame is proportional to the element in the sample. During the analysis, the instrument draws a calibration curve of absorbency against concentration of prepared standards. The curve was used to determine the concentration of the elements in the test sample. All samples were analyzed according to standard methods [3]. The results were compared with Federal Ministry of Environment [4], World Health Organization, [10].

\section{Results and Discussion}

The distribution of some trace element in surface and groundwater samples in Agepanu and environs have 
Table 1. Obtained concentrations of trace elements in Agepanu and Environs

\begin{tabular}{|c|c|c|c|c|c|c|}
\hline \multirow{2}{*}{$\begin{array}{l}\text { Parameters } \\
(\mathrm{mg} / \mathrm{l})\end{array}$} & \multicolumn{6}{|c|}{ Sample Locations } \\
\hline & Agepanu & Afiangbe & Gbokili & Okayan & $\begin{array}{c}\text { Concentration } \\
\text { range }(\mathrm{mg} / \mathrm{l})\end{array}$ & $\begin{array}{c}\text { Mean concentration } \\
(\mathrm{mg} / \mathrm{l})\end{array}$ \\
\hline Zinc (Zn) & 0.104 & 0.099 & 0.084 & 0.100 & $0.084-0.104$ & $0.097 \pm 0.049$ \\
\hline Lead (pb) & $<0.002$ & $<0.002$ & $<0.002$ & $<0.002$ & $<0.002$ & $0.002 \pm 0.00$ \\
\hline Chromium Cr) & 0.012 & 0.087 & 0.027 & 0.007 & $0.007-0.087$ & $0.033 \pm 0.017$ \\
\hline Cadmium (Cd) & $<0.005$ & $<0.005$ & $<0.005$ & $<0.005$ & $<0.005$ & $0.005 \pm 0.00$ \\
\hline Nickel (Ni) & $<0.002$ & $<0.002$ & $<0.002$ & $<0.002$ & $<0.002$ & $0.002 \pm 0.00$ \\
\hline Copper $(\mathrm{Cu})$ & 0.099 & 0.089 & 0.075 & 0.092 & $0.075-0.099$ & $0.089 \pm 0.357$ \\
\hline
\end{tabular}

Table 2. Safe limits (as per World Health Organization, [10] and Federal Ministry of Environment, [4]) and acceptable limits for drinking purpose and adverse effect on living bodies

\begin{tabular}{|c|c|c|c|c|}
\hline $\begin{array}{l}\text { Parameters } \\
(\mathrm{mg} / \mathrm{l})\end{array}$ & $\begin{array}{c}\text { Who* } \\
\text { Limit }(\mathrm{mg} / \mathrm{l})\end{array}$ & $\begin{array}{c}\mathrm{FMEV}^{* *} \\
(\mathrm{mg} / \mathrm{l})\end{array}$ & $\begin{array}{c}\text { Obtained } \\
\text { Concentration } \\
\text { Range (mg/l) }\end{array}$ & Effect on living bodies \\
\hline Lead $(\mathrm{Pb})$ & 0.05 & 1.00 & $0.002 \pm 0.00$ & $\begin{array}{l}\text { Several inflammation in gastrointestinal track, causes paralysis, } \\
\text { mental disorder, visual disturbance, anemia burning in mouth e.t.c }\end{array}$ \\
\hline Chromium (Cr) & 0.05 & 1.00 & $0.033 \pm 0.017$ & $\begin{array}{l}\text { Carcinogernic activity (cancer), can produce coetaneous and nasal } \\
\text { mucus membrane ulcer and dermatitis, lung tumors }\end{array}$ \\
\hline Nickel (Ni) & 0.02 & 0.02 & $0.002 \pm 0.00$ & $\begin{array}{l}\text { May be carcinogenic, can react with Deoxyribonucleic acid (DNA), } \\
\text { resulting in DNA damage }\end{array}$ \\
\hline Copper $(\mathrm{Cu})$ & 1.00 & 1.00 & $0.089 \pm 0.357$ & $\begin{array}{l}\text { Astringent taste but essential element for metabolism deficiency } \\
\text { results is anemia in infants, excess may result in liver damage. }\end{array}$ \\
\hline Cadmium (Cd) & 0.01 & 0.01 & $0.005 \pm 0.00$ & Carcinogenic, lung tumors, causes skin damage \\
\hline Zinc $(\mathrm{Zn})$ & 5.0 & 5.0 & $0.097 \pm 0.049$ & $\begin{array}{l}\text { Causes astringent taste and opalescence in water, essential element } \\
\text { in human metabolism }\end{array}$ \\
\hline
\end{tabular}

${ }^{*}$ Source: (World Health Organization [10]).

${ }^{*}$ Source: Federal Ministry of Environment [4].

been depicted in Table 1. Safe limits (as per World Health Organization, Federal Ministry of Environment) and the acceptable limits for drinking purpose and adverse effects on living bodies are shown in Table 2 .

All the surface and ground water samples showed some concentrations of trace elements. The description each element is given below:

\subsection{Zinc}

The surface water and ground water sample collected from various sites in the study area contained zinc whose concentration ranges from $0.084-0.104 \mathrm{mgl}^{-1}$ with an average value of $0.097 \mathrm{mgl}^{-1}$. This does not exceed the WHO [10] and FMEV [4] allowable standards of $5 \mathrm{mgl}^{-1}$. Zinc is an essential plant and animal nutrient. All the samples collected from all sources are below the permissible limit for zinc.

\subsection{Lead}

Lead is a very toxic element which accumulates in the skeletal structure of man and animal. The range concentration for lead is below $0.002 \mathrm{mgl}^{-1}$ for all water samples. This does not exceed the WHO [10] allowable standard of $0.05 \mathrm{mgl}^{-1}$ and FMEV [4] allowable standard of $1.0 \mathrm{mgl}^{-1}$.

\subsection{Chromium}

The maximum permissible limit for chromium in drinking water according to WHO and FMEV is $0.05 \mathrm{mgl}^{-1}$ and 1.0 $\mathrm{mgl}^{-1}$ respectively. Small amount of chromium is essential for mammals but its excess produce harmful effects. The obtained data shows that the chromium content in the water samples is within the limits prescribed by various authorities. 


\subsection{Cadmium}

The concentration range of cadmium in the water samples is less than 0.005 which is below the standard of $0.01 \mathrm{mgl}^{-1}$ by WHO, (1992). This implies a low level of anthropogenic effects on the environment.

\subsection{Nickel}

The permissible concentration of nickel in drinking water set up by various authorities is $0.02 \mathrm{mgl}^{-1}$. All the samples are within the permissible limit.

\subsection{Copper}

According to limits prescribed by various authorities $[10,4]$; it is found that the average value of copper in all water sample were below the permissible limit.

\section{Conclusion}

All the analyzed water quality parameters were far below the WHO [10] and FMEV [5] permissible limits for drinking water. Concentrations of most parameters studied were generally similar, showing that the existing conditions within the study area were almost the same. Chromium enriched refuse should be properly treated and then disposed. Construction of groundwater on dumping sites or its immediate vicinity should be avoided as chromium pollution relates to point source. It is also recommended that adequate monitoring efforts should be put in place to ensure that untreated waste and effluents are not introduced into rivers and streams. Also geochemical analysis of the surface and ground water in the area should be done always in order to obtain data bank for effective monitoring of the water quality trend and environmental impact.

\section{References}

1. Akhilesh J, Savita D et al. (2009). Some trace elements investigations in groundwater of Bhopal and Sehore District in Madhya Pradesh, India, Journal of Applied Sciences and Environmental Management, vol 13(4), 47-50.

2. Angino E E, Magnuso L M et al. (1974). Mineralogy of suspended sediment and concentration $\mathrm{Fe}, \mathrm{Mn}, \mathrm{Ni}, \mathrm{Cu}$ and $\mathrm{Pb}$ and in water and $\mathrm{Fe}, \mathrm{Mn}$ and $\mathrm{Pb}$ in suspended load of selected Kansas streams. Water Resources Research, vol 10(6), 1187-1191.

3. APHA (1992). Standard method of waste examination, American Public Health Association, USA.

4. FMEV (1992). Drinking water quality standards, Federal Ministry of Environment, Lagos.

5. Kaizer A N (2010). Soil and hydro geochemical characteristics around Kwale and its environs, Southwestern Nigeria, Journal of Applied Sciences, vol 13(2), 8977-8985.

6. Lone M I, Latif M Aslam et al. (1999). Water pollution in Pakistan-source and remedies, Pakistan Journal of Arid Agriculture, vol 2, 1-6.

7. Meranger J C, Subramaion K S (1979). A national survey for cadmium, chiromium, copper, lead, zinc, calcium and manganese in Canadian drinking water supplies, Environmental Science and Technology, vol 13, 707-711.

8. Midrar-ul-haq R A K, HajikanPunu M S et al. (2005). Surface and groundwater contamination in NWFP and Sindh Provinces with respect to trace elements, International Journal of Agriculture and Biology, vol 7, No. 2, 214-217.

9. Nasreen S, Khawaja M A et al. (1995). Pollution due to effluent from tanneries/leather industries in NWEP, Pakistan, J. Sci. Ind. Res., vol 30, 215-2190.

10. WHO (1993). Guidelines for drinking water quality, vol 1-2, Geneva, Switzerland. 